\title{
異形鉄筋のコンクリート内の定着性状に及ぼす拘束の効果に関する実験的研究 EXPERIMENTAL STUDY ON CONCRETE CONFINEMENT AROUND A DEFORMED STEEL BAR DEVELOPING STRAIGHT
}

\author{
德 重 充*, 石橋一彦**, 中野克彦*** \\ Mitsuru TOKUSHIGE, Kazuhiko ISHIBASHI and Katsuhiko NAKANO
}

\begin{abstract}
Vertical wall reinforcing bars of a boxed wall precast concrete structure in Japan must be anchored straight in the foundation beam. Sometimes, the beam width may not be sufficient to develop anchorage strength in the concrete although the AIJ (Architectural Institute of Japan) Standard for Structural Calculation of Reinforced Concrete Structure requires minimum concrete volume for the development of deformed bars. A series of pull-out tests were carried out to investigate structural performance of anchored bars using various prototype specimens. The purpose of the test series was to study the effect of various parameters and to clarify the failure mechanism. A new series of tests were carried out using high strength deformed bars and varying the foundation beam widths. The anchored bars were pulled out from the base beam exhibiting the relationship between maximum bond stresses and flexural stresses with in the beam.
\end{abstract}

Keywords: Axial stress, Bond stress, Bond slip, Concrete flexural stress, Straight development 軸応力度，付着応力度，付着すべり，コンクリート曲げ応力度，直線定着

\section{1. はじめに}

鉄筋コンクリート構造における鉄筋の定着は鉄筋径に対して十分 なコンクリートの体積があることを前提にして, その設計方法が $\mathrm{RC}$ 規準 1)に規定されている。また壁式鉄筋コンクリート造設計・計 算規準・同解説 2)においては RC 規準に解説している必要定着長実 験式で，スラブや直交壁の拘束の有無の係数を代入する, 定着長の 標準設計式を規定している。

一方, 材料試験としての付着強度試験に関して, 海外ではASTM, RILEM，BS 等の規準がある。ASTM，BS の両規準はともに，コン クリートプリズムから鉄筋を引き抜く試験方法を採用しており, ASTM はコンクリートの付着割裂破壊で付着強度を決定するが, $\mathrm{BS}$ は割裂き破壊しないようにフープで補強されているのが特徵で ある。RILEM 規準は前 2 者とほぼ同様の形式の引き抜き試験法と 梁型の試験法とがある。日本では(財)建材試験センターにおいて, JSTM C 2101 が 1999 年に規格化された。JSTM 規格は海外の諸規 準を参考に作られたものであり, ほぼ同一内容が日本土木学会でも 規格化されている。以上，いずれの試験法も鉄筋の抜け出し量があ る一定の值の時の平均付着応力度を算出し評価するものとなってい る。これらの引き抜き試験法 ${ }^{3), 4}$ ) は定着長さが $4 \mathrm{~d}$ (d は鉄筋径) で あり，比較的簡単に試験ができる方法である。

プレキャスト鉄筋コンクリート構造の住宅の基礎のように梁幅が
$220 \mathrm{~mm}$, 梁せいが $800 \mathrm{~mm}$ 程度の断面に, 上部構造を定着するため のアンカー筋として，異形鉄筋を鉛直に直線定着する場合がある。 このような基礎梁に定着する鉛直アンカー筋に対しては，たとえ主 筋や肋筋で拘束されていても，梁幅の薄さに由来する拘束力不足で 定着強度が低下寸る懸念があるが，通常の拘束効果を無視した定着 長でよいとする設計となっている。

本研究では，先ず上記のような薄肉部材の基礎に対する鉛直アン カー筋の設計例（定着長 40d）に対して，実部材寸法の試験体を作 製して，アンカー筋（D19,SD345）の引き抜き実験を実施すること によりその構造安全性を実証することにした。施工の合理化のため に，アンカー筋の位置にシース管を埋設してコンクリート打設後に 無収縮モルタルを充填させ，アンカー筋を定着させる工法（以下， スリーブ定着工法とする）を試験体の要因に取り入れ，一般の直接 定着法と比較した。

上記の実証実験では全長に亘る付着破壊性状が把握できないので, アンカー筋の材料強度をSD980 まで高めて全長付着破壊を起こさ せる実験を追加した。この実験を分析実験と名付けて,梁幅を $180,220,330,440 \mathrm{~mm}$ 変化させた。

実証実験および分析実験において, アンカー筋の引抜き荷重によ って基礎梁に曲げモーメントが生じる加力方法が採用された。

\footnotetext{
※本論文は参考文献 5，6，7）について集成し篦めたものである。 千葉工業大学工学研究科工学専攻 大学院生・修士 (工学)

** 千葉工業大学 名誉教授・博士 (工学)

*** 千葉工業大学 教授 $\cdot$ 博士 (工学)
}

Engineering Specialty, Engineering Postgraduate Course, Chiba Institute of Technology, M.Eng.

Prof. Emeritus, Chiba Institute of Technology, Dr.Eng. Prof., Chiba Institute of Technology, Dr.Eng. 


\section{2. 実用上の安全性}

\section{1 実証実験の試験体}

図 1 に試験体形状を示す。試験体は梁幅×梁せい $=220 \mathrm{~mm} \times 760 \mathrm{~mm}$, 試験体全長 $2500 \mathrm{~mm}$ とし，プレキャス卜壁式鉄筋コンクリート造基 礎立ち上がり部分を想定したものとなっている。主筋は 4-D16

(SD345)，せん断補強筋は 2-D10（SD295A）とし，アンカー筋に は D19 異形鉄筋を用い試験体中央に配筋した。定着長さは梁せいの $760 \mathrm{~mm}$ (40d）とした。コンクリートの設計基準強度は $21 \mathrm{~N} / \mathrm{mm}^{2}$ とした。

実証実験の試験体は 4 体であり, 実験変数は直接定着工法とスリ 一ブ定着工法の 2 種の定着方法と 2 種のアンカー筋の材料である。 スリーブ定着工法に用いたシース管には, メッキ鋼帯 (JIS G 3302)

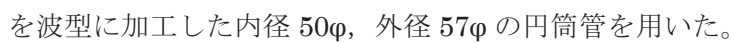

コンクリートは図 1 の梁上面から打設した。スリーブ定着のグラ ウト方法は市販の加水練り混ぜ式の袋詰め一体型無収縮モルタルを 用い，練り混ぜ 3 分の後，上面のシース管とアンカー筋の隙間より 流し込み, $6 \phi$ の鋼線でゲージを傷つけないように静かに突き固め る方式とした。

実証実験の D19 のアンカー筋材料として, SD345 の竹節鉄筋を用 いた。さらに定着強度を確認するために SD685 のねじ節鉄筋の試 験体を追加した。以上の試験体の実験変数の組み合わせとアンカー 筋およびコンクリートの力学的性質を表 1 に示す。

\section{2 加力方法および変形, 歪度測定方法}

図 2 に加力方法および抜け出し量, 変形測定方法を示す。同図に 示すように, アンカー筋を引き抜くためにセンターホールジャッキ と加力梁を用いた。試験体上部にす心゙り支承のローラー支点を介し て加力梁を載せる。中央のアンカー筋から両端の反力支点までの梁 の断面には大きなせん断力が働く。荷重の増大により,この区間の せん断ひびわれが発生したときの，45 方向の斜めひびわれが反力 支点間の内側に来るようにスパンを定めた。加力梁の上部中央の芯 に合わせてセンターホールジャッキを据え, アンカー筋をジャッキ およびその上のロードセルの中心軸を通って上部に突き出させてい る。アンカー筋の先端には定着板が溶接されており, シアキーを介 してアンカー筋への引張り荷重が載荷される。

本実験ではアンカー筋のコンクリートからの抜け出しと, 梁のた わみを測定した。抜け出しについては, 載荷端側コンクリート表面 から伸びているアンカー筋に測定治具を取り付け, そこへ変位計 $(\delta$

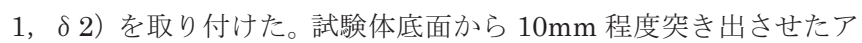
ンカー筋の自由端変位も測定した（ $\delta 9 ）$ 。梁のたわみについては, 梁両側面の梁軸線上にゲージホルダーを取り付けて, それを基準点 として測定した。たわみ測定点は梁せいの上面, 中段, 下面の三か 所とし，試験体の表裏を同時に測定した（ $\delta 3 \sim \delta 8 ） 。$

歪度の測定は歪ゲージを貼り付けて行い, アンカー筋の 1 か所に ついて表裏 2 点に貼り付けた。貼り付け位置は, 図 4 の左に示すよ うに, 載荷端側コンクリート表面から $100 \mathrm{~mm}$ 上のアンカー筋露出 部と，コンクリート中の定着範囲を 4 区間に分け，3 か所の区間の 境界に歪ゲージを貼り付けた。加力ルールはアンカー筋材料試験か ら得た実応力度 $\sigma \mathrm{y}$ を採用し，1/3 $\sigma \mathrm{y} ， 2 / 3 \sigma \mathrm{y}$ までを 2 回ずつ片振 りの荷重制御で繰り返し, アンカー筋降伏後は変形制御とし, 降伏 時の抜け出し $\delta \mathrm{y}$ を 2 倍，4倍，8倍と漸増して加力した。

\section{表 1 試験体のアンカー筋とコンクリートのカ学的性状}

\begin{tabular}{|c|c|c|c|c|c|c|c|c|}
\hline \multirow{2}{*}{ No. } & \multirow{2}{*}{$\begin{array}{l}\text { 定着 } \\
\text { 方法 }\end{array}$} & \multicolumn{4}{|c|}{$\begin{array}{c}\text { アンカー筋 D19 の材料と } \\
\text { 力学的性質 }\left(\mathrm{N} / \mathrm{mm}^{2}\right)\end{array}$} & \multicolumn{3}{|c|}{$\begin{array}{c}\text { コンクリートの } \\
\text { カ学的性質 }\left(\mathrm{N} / \mathrm{mm}^{2}\right) \\
\text { ※()内はスリーブ } \\
\text { 充てんモルタル }\end{array}$} \\
\hline & & 材料 & $\begin{array}{c}\text { 降 } \\
\text { 伏 } \\
\text { 点 }\end{array}$ & $\begin{array}{l}\text { 引張 } \\
\text { 強さ }\end{array}$ & $\begin{array}{l}\text { ヤング } \\
\text { 係数 } \\
10^{-5}\end{array}$ & $\begin{array}{l}\text { 圧縮 } \\
\text { 強度 }\end{array}$ & $\begin{array}{l}\text { 割裂 } \\
\text { 強度 }\end{array}$ & $\begin{array}{l}\text { ヤング } \\
\text { 係数 } \\
10 \wedge 4\end{array}$ \\
\hline 1 & $\begin{array}{l}\text { スリ } \\
\text { ーブ }\end{array}$ & \multirow{2}{*}{$\begin{array}{l}\text { SD345 } \\
\text { (竹節) }\end{array}$} & \multirow[t]{2}{*}{380} & \multirow[t]{2}{*}{568} & \multirow[t]{2}{*}{1.87} & \multirow{2}{*}{$\begin{array}{r}30.8 \\
(84.0)\end{array}$} & \multirow{2}{*}{$\begin{array}{c}2.17 \\
(3.66)\end{array}$} & \multirow{2}{*}{$\begin{array}{c}2.43 \\
(2.66)\end{array}$} \\
\hline 2 & 直接 & & & & & & & \\
\hline 3 & $\begin{array}{l}\text { スリ } \\
\text { ーブ }\end{array}$ & \multirow{2}{*}{$\begin{array}{l}\text { SD685 } \\
\text { (叔じ節) }\end{array}$} & \multirow[t]{2}{*}{723} & \multirow[t]{2}{*}{909} & \multirow[t]{2}{*}{1.92} & \multirow{2}{*}{$\begin{array}{c}27.7 \\
(86.2)\end{array}$} & \multirow{2}{*}{$\begin{array}{c}2.46 \\
(3.40)\end{array}$} & \multirow{2}{*}{$\begin{array}{c}2.93 \\
(3.47)\end{array}$} \\
\hline 4 & 直接 & & & & & & & \\
\hline
\end{tabular}
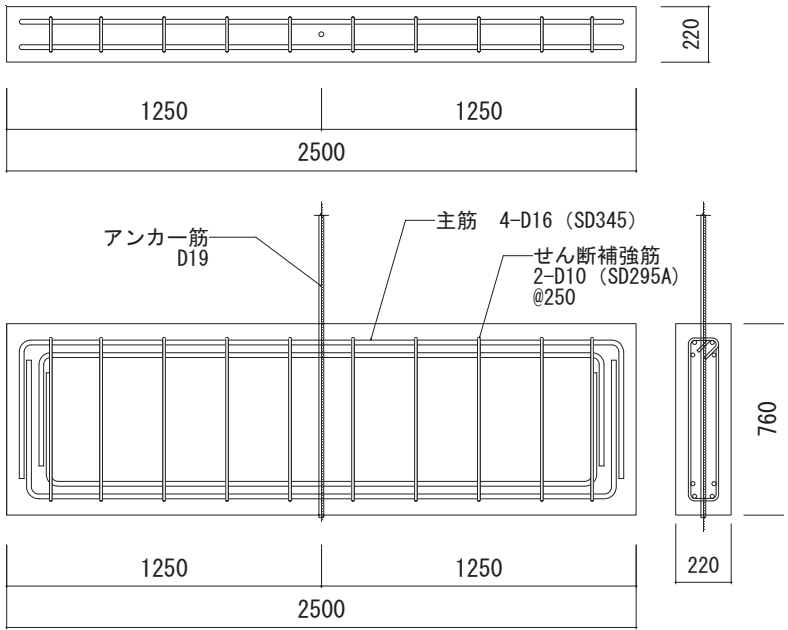

図 1 試験体形状

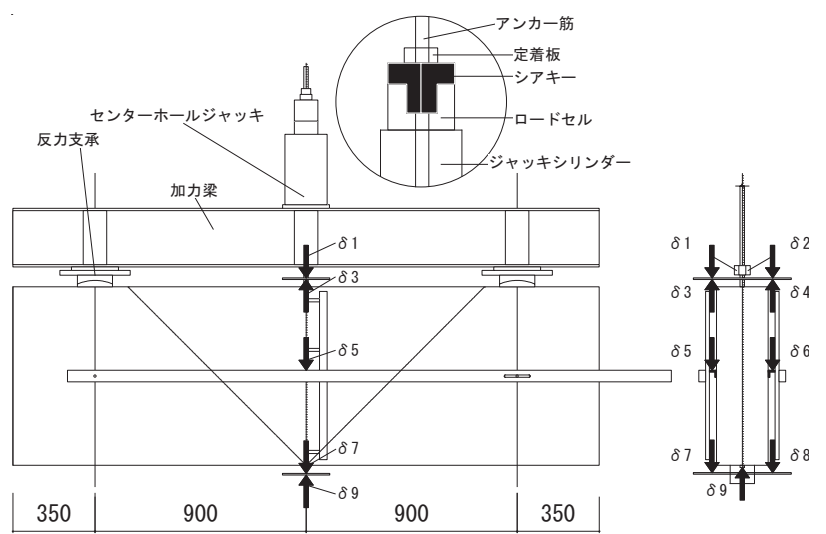

図 2 加力方法および抜け出し, 変形量測定方法 SD345 SD685

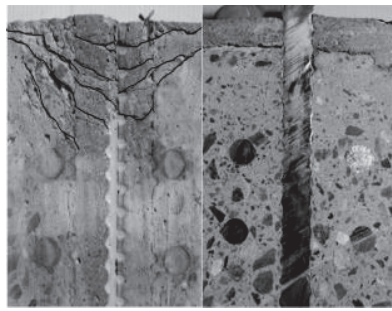

No. 1
No. 2

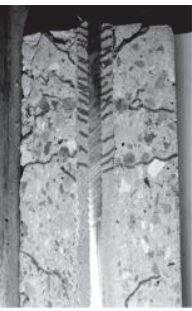

№. 3

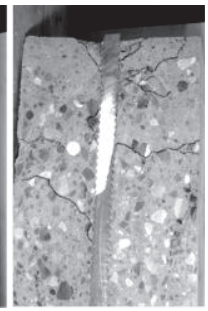

No. 4 

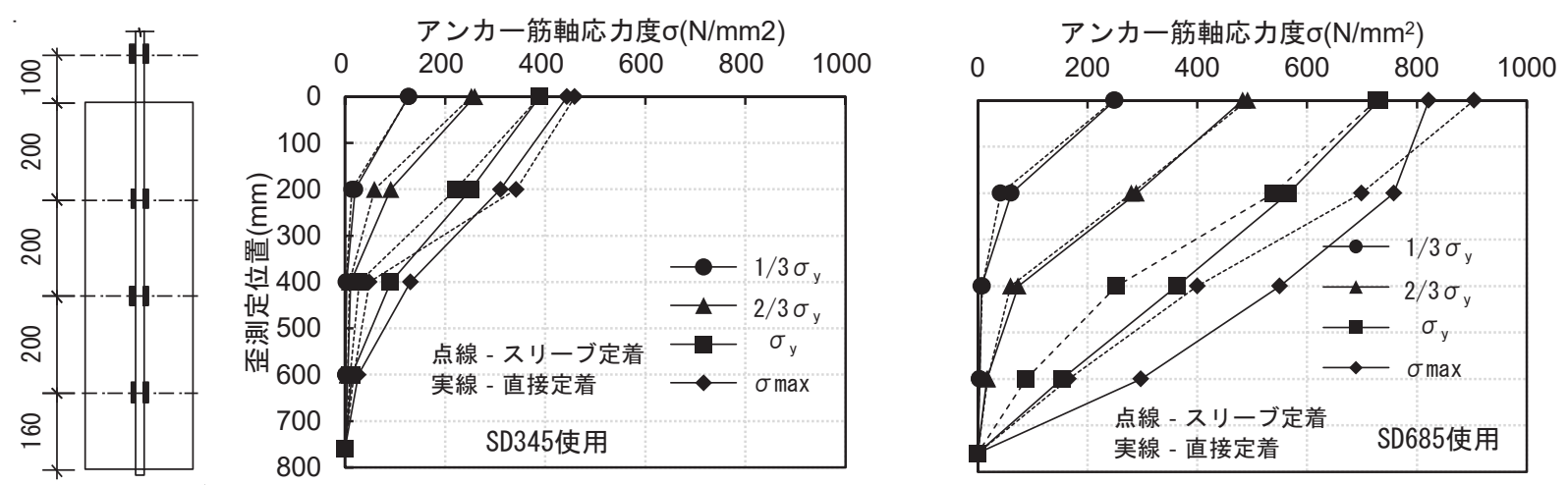

図 4 アンカー筋の軸応カ度分布
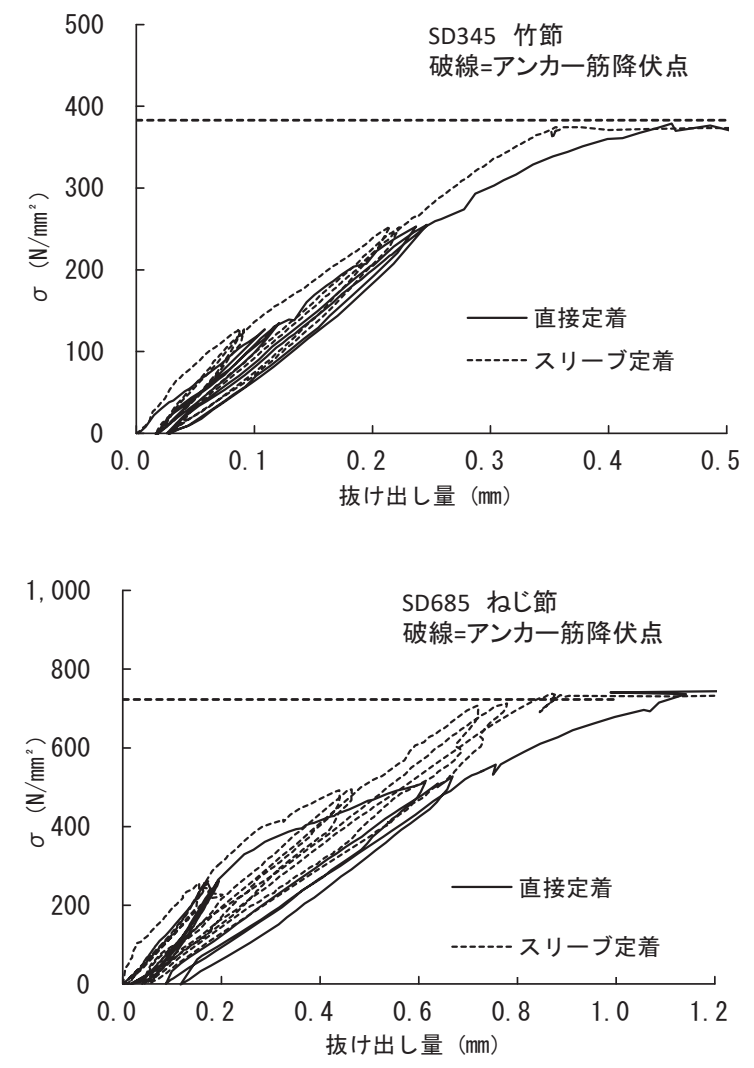

図 5 実証実験 荷重 - 抜け出し量関係

\section{3 実証実験の実験結果}

\section{(1) 破壊状況}

破壊形式は SD345（No.1，No.2）および SD685（No.3，No.4） の 4 試験体ともにアンカー筋が降伏し, その後は加力ルールに従っ て規定の抜け出し量まで載荷し実験を終了した。図 3 の破壊状況に 示すように, 実験後に試験体中央のアンカー筋に沿って試験体を切 断し, 試験体内部のひびわれ発生状況を確認したところ, SD345 で は No.1 だけにアンカー筋定着起点付近にコーン状のひびわれが発 生している。SD685 では双方の定着方式で試験体断面の中央までひ びわれが発生しており, 鉄筋の応力が SD345 より深部へ到達して いることがわかる。

（2）アンカー筋の軸応力度性状
図 4 に竹節 SD345 およびねじ節 SD685 の軸応力度分布を示す。 同図では載荷側の歪測定位置を 0 とし, $200 \mathrm{~mm}$ 間隔で 4 区間を分け た測定点の軸応力度分布を示す。竹節を使用した SD345 では直接定 着よりスリーブ定着の方が測定位置 $400 \mathrm{~mm}$ まで鉄筋軸力のコンク リートへの応力伝達が大きく, 一方, 敉じ節 SD685 では最大軸応力 度 $500 \mathrm{~N} / \mathrm{mm}^{2}$ までの範囲では, スリーブ定着と直接定着では軸力分 布が重なっており，スリーブ定着の効果は表れていない。しかし， $700 \mathrm{~N} / \mathrm{mm}^{2}$ 以上の荷重では, 測定位置 $400 \mathrm{~mm}$ と $600 \mathrm{~mm}$ の位置でス リーブ定着の効果が明瞭となった。

\section{4 実証実験の結論}

実証実験の試験体においては, 図 5 に示すように, アンカー筋の 降伏によって載荷端の抜け出しは増大寸るが, 強度は破断強度近く まで維持され, 自由端までの抜け出しは生じなかった。このことに より, 反力支点をアンカー筋から離した引き抜き加力状態での定着 強度上の安全性は確かめられた。一方, 短期荷重相当の $2 / 3 \sigma \mathrm{y}$ で 除荷した時の残留変形は, SD 345 およびSD685 の直接定着の場合, それぞれ 0.04 および $0.14 \mathrm{~mm}$ 程度であった。スリーブ定着の場合は, これらと比較して小さい。降伏時のすべり変形も直接定着に比較し てスリーブ定着の場合は小さい。すなわち，アンカー筋設計時に抜 け出し変形に制限があるときは, 高強度鉄筋は対象から外し, さら に変形条件が厳しいときには, スリーブ定着とすることが望ましい。

\section{3. $40 \mathrm{~d}$ 直線定着の付着破壊過程}

\section{1 分析実験の試験体と実験方法}

表 2 に分析実験の試験体および材料の力学的性質, 図 6 に分析実 験の試験体形状および配筋を示す。主筋およびあばら筋の補強量と

\section{表 2 分析実験アンカー筋とコンクリートのカ学的性質}

\begin{tabular}{|c|c|c|c|c|c|c|c|c|}
\hline \multirow[b]{2}{*}{ No. } & \multirow{2}{*}{$\begin{array}{l}\text { 梁 } \\
\text { 幅 } \\
(\mathrm{mm})\end{array}$} & \multicolumn{4}{|c|}{$\begin{array}{c}\text { アンカー筋 D19 の材料と力学的性質 } \\
\left(\mathrm{N} / \mathrm{mm}^{2}\right)\end{array}$} & \multicolumn{3}{|c|}{$\begin{array}{c}\text { コンクリートの力学的 } \\
\text { 性質 }\left(\mathrm{N} / \mathrm{mm}^{2}\right)\end{array}$} \\
\hline & & 材料 & 降伏点 & $\begin{array}{l}\text { 引張 } \\
\text { 強さ }\end{array}$ & $\begin{array}{c}\text { ヤング } \\
\text { 係数 } \\
10^{\wedge} 5\end{array}$ & $\begin{array}{l}\text { 圧縮 } \\
\text { 強度 }\end{array}$ & $\begin{array}{l}\text { 割裂 } \\
\text { 強度 }\end{array}$ & $\begin{array}{c}\text { ヤング } \\
\text { 係数 } \\
10^{\wedge} 4\end{array}$ \\
\hline 5 & 180 & \multirow{4}{*}{$\begin{array}{l}\text { SD980 } \\
\text { (ねじ節) }\end{array}$} & \multirow[b]{2}{*}{1027} & \multirow[b]{2}{*}{1106} & \multirow[b]{2}{*}{1.84} & \multirow[b]{2}{*}{28.6} & \multirow[b]{2}{*}{2.10} & \multirow[b]{2}{*}{2.37} \\
\hline 6 & 220 & & & & & & & \\
\hline 7 & 330 & & \multirow[b]{2}{*}{1010} & \multirow[b]{2}{*}{1092} & \multirow[b]{2}{*}{1.80} & \multirow[b]{2}{*}{24.6} & \multirow[b]{2}{*}{2.08} & \multirow[b]{2}{*}{2.45} \\
\hline 8 & 440 & & & & & & & \\
\hline
\end{tabular}



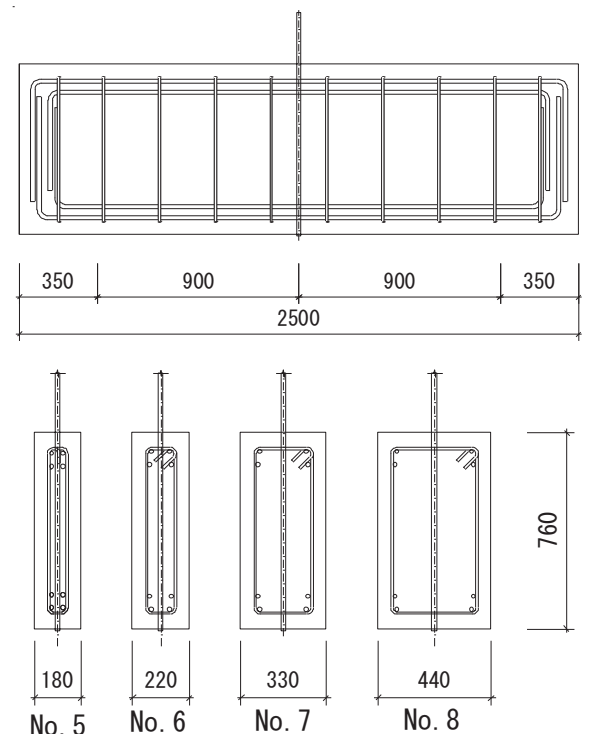

図 6 分析実験の試験体形状および配筋
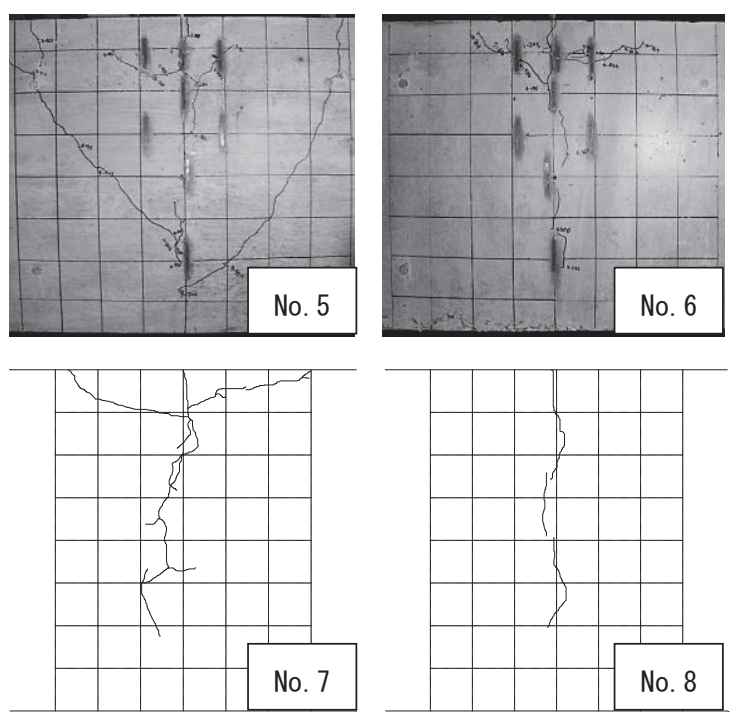

図 7 分析実験 破壊状況
軸応力度測定点

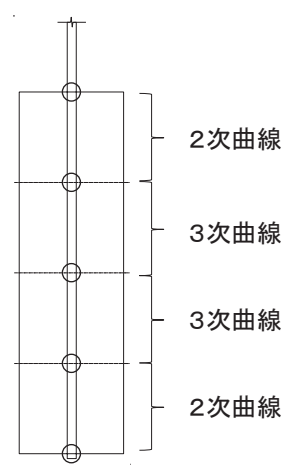

図 8 近似式計算概念
コンクリートの設計基準強度は同一である。検証実験のアンカー筋 材質より強度の高い, 超高強度の SD980 のアンカー筋を用いて定 着区間全域で付着破壊過程を確認する。試験体の梁幅を 180,220 , 330, 440mm の 4 種類として, 梁幅の拘束効果を確認する。

載荷方法と測定方法はすべて実証実験と同様である。加力ルール は, 3 回ずつの片振り荷重の鉄筋軸応力度を, $250,500,750 \mathrm{~N} / \mathrm{mm}^{2}$ と上げ, 最終サイクルはアンカー筋の破断に近い荷重まで載荷する。

\section{2 分析実験の実験結果}

\section{(1) 破壊状況}

図 7 に分析実験のひびわれ状況を示す。4 試験体ともに定着長さ 全長にわたる付着破壊により，アンカー筋の抜出しを確認した。梁 幅 180mm（No.5）, 220mm（No.6）, 330mm（No.7）はアンカー 筋の抜出しと共に, 載荷端側アンカー筋から縦横斜めの方向に放射 状にひびわれが発生し, 最終的にアンカー筋が抜出すときの破壞は, 放射状のひびわれがアンカー筋回りで円形につながり, 深さ方向の コンクリートが円錐状に抜け出した。図 7 左上の写真より, No.5 は試験体側面自由端側から 45 度方向に延びるせん断ひびわれが発 生しており，これは他試験体には見られない。同図右下のひびわれ 図より，440mm（No.8）ではコンクリート側面の斜めひびわれは 皆無であり，曲げひびわれのみであった。

\section{（2）アンカー筋の鉄筋軸応力度と付着応力度}

載荷端の軸応力度は荷重から算出し, コンクリート内部では軸歪 度の測定值から算定し, 自由端では 0 とした。これらの実験值を利 用して, 次に述べる, 連続関数の軸応力度分布曲線を求めた。

図 8 に示寸ように, 載荷端または自由端からの軸応力度 $\sigma$ は, 隣 接する測定点までは，鉄筋位置 $x$ の次関数であるとする。

$$
\sigma=a+b x+c x^{2}
$$

この軸応力度と付着応力度は, 次の式 (2), (3), (4) の関係が ある。 $a_{a}$ は鉄筋の断面積， $\psi$ は鉄筋の周長である。

$$
\begin{aligned}
& \frac{d \sigma}{d x}=b+2 c x \\
& \tau=\frac{a_{a}}{\psi} \frac{d \sigma}{d x} \\
& \tau \frac{\psi}{a_{a}}=\frac{d \sigma}{d x}
\end{aligned}
$$

載荷端または自由端に連続する測定点番号を $(i, j, j 0)$ とする。 $\sigma$ の 分布曲線式 $(1)$ の係数項を, $(i, j)$ 点の応力測定值 $\left(\sigma_{i}, \sigma_{j}\right)$ と, 2 番目の測定点 $(j)$ における付着応力度 $\left(\tau_{j}\right)$ によって決定する。 この $\left(\tau_{j}\right)$ は 1 番目の測定軸応力度 $\left(\sigma_{i}\right)$ と 3 番目の測定軸応力度 $\left(\sigma_{j 0}\right)$ との間の勾配の関数（平均付着応力度）と仮定する。

$$
\begin{gathered}
\left(\begin{array}{c}
\sigma_{i} \\
\tau_{j} \psi / a_{a} \\
\sigma_{j}
\end{array}\right)=\left[\begin{array}{ccc}
1 & x_{i} & x_{i}{ }^{2} \\
0 & 1 & 2 x_{j} \\
1 & x_{j} & x_{j}{ }^{2}
\end{array}\right]\left(\begin{array}{l}
a \\
b \\
c
\end{array}\right) \\
\left(\begin{array}{l}
a \\
b \\
c
\end{array}\right)=\left[\begin{array}{ccc}
1 & x_{i} & x_{i}{ }^{2} \\
0 & 1 & 2 x_{j} \\
1 & x_{j} & x_{j}{ }^{2}
\end{array}\right]^{-1}\left(\begin{array}{c}
\sigma_{i} \\
\tau_{j} \psi / a_{a} \\
\sigma_{j}
\end{array}\right) \\
\tau_{j} \psi / a_{a}=-\left(\sigma_{i}-\sigma_{j 0}\right) /\left(x_{i}-x_{j 0}\right)
\end{gathered}
$$

中間の測定点間では三次関数とする。

$$
\sigma=a+b x+c x^{2}+d x^{3}
$$

(8)式の未定係数の決定は前記の端部における方法と同様に行う。 すなわち連続する 4 点の $\sigma$ の測定值を， $\left(\sigma_{i 0}, \sigma_{i}, \sigma_{j}, \sigma_{j 0}\right)$ とする。 さらに付着応力度 $\left(\tau_{i}\right)$ および $\left(\tau_{j}\right)$ を, $(i, j)$ 点それぞれに隣接する 2 点間の平均付着応力度であると仮定する。

$$
\frac{d \sigma}{d x}=b+2 c x+3 d x^{2}
$$




$$
\begin{gathered}
\left(\begin{array}{l}
a \\
b \\
c \\
d
\end{array}\right)=\left[\begin{array}{cccc}
1 & x_{i} & x_{i}{ }^{2} & x_{i}{ }^{3} \\
0 & 1 & 2 x_{i} & 3 x_{i}{ }^{2} \\
0 & 1 & 2 x_{j} & 3 x_{j}{ }^{2} \\
1 & x_{j} & x_{j}{ }^{2} & x_{j}{ }^{3}
\end{array}\right]^{-1}\left(\begin{array}{c}
\sigma_{i} \\
\tau_{i} \psi / a_{a} \\
\tau_{j} \psi / a_{a} \\
\sigma_{j}
\end{array}\right) \\
\tau_{i} \psi / a_{a}=-\left(\sigma_{i 0}-\sigma_{j}\right) /\left(x_{i 0}-x_{j}\right) \\
\tau_{j} \psi / a_{a}=-\left(\sigma_{i}-\sigma_{j 0}\right) /\left(x_{i}-x_{j 0}\right)
\end{gathered}
$$

（1）および（8）によって計算した軸応力度分布の例を図 9 に 示す。（2）または（9），および（3）式によって付着応力度を求め た。その分布を図 10 に示す。縦軸は測定位置を示し, 横軸は付着 応力度を示している。同図内の 00 はそのサイクルの最大荷重であ る。同図は，4つの荷重レベルの, 繰り返し荷重の初めの荷重サイ クルについて示している。荷重および荷重レベルの上昇に従い, 最 大付着応力度の位置が下部へ移行している。このことは梁幅 4 種類 の試験体すべてにおいて同様の結果を得ている。

\section{（3）付着応力度 $(\tau)$ - すべり（S）関係}

No.5 と No.6 の試験体においては，コンクリートの側面に歪ゲ ージを貼って, コンクリートの鉛直方向歪度分布を求めた。自由端 からこの歪度を各鉄筋位置まで積分して, 鉄筋軸歪度の積分から差 し引いて自由端すべりを加えたものを, 鉄筋とコンクリート間の相 対すべりと定義した。その結果, コンクリートの歪のすべりに対す る影響は微小であり, 載荷端の計算值は直接外部から測定した值に 近似した。No.7 梁幅 $330 \mathrm{~mm}$ と No.8 梁幅 $440 \mathrm{~mm}$ の試験体では鉄 筋の歪度の積分を自由端すべりに加えてすべり值とした。以上の結

果，付着応力度とすべりの関係を任意の位置で推定できた。図 11 に, 梁幅 220 の試験体について, アンカー筋の定着位置ごとの, $\tau$
$-\mathrm{S}$ 曲線を示す。定着位置が載荷端の $0 \mathrm{~d}$ から $25 \mathrm{~d}$ の位置までは, すべりが $0.2 \mathrm{~mm}$ 以下で最大あるいはそれに近い付着応力度に達し，
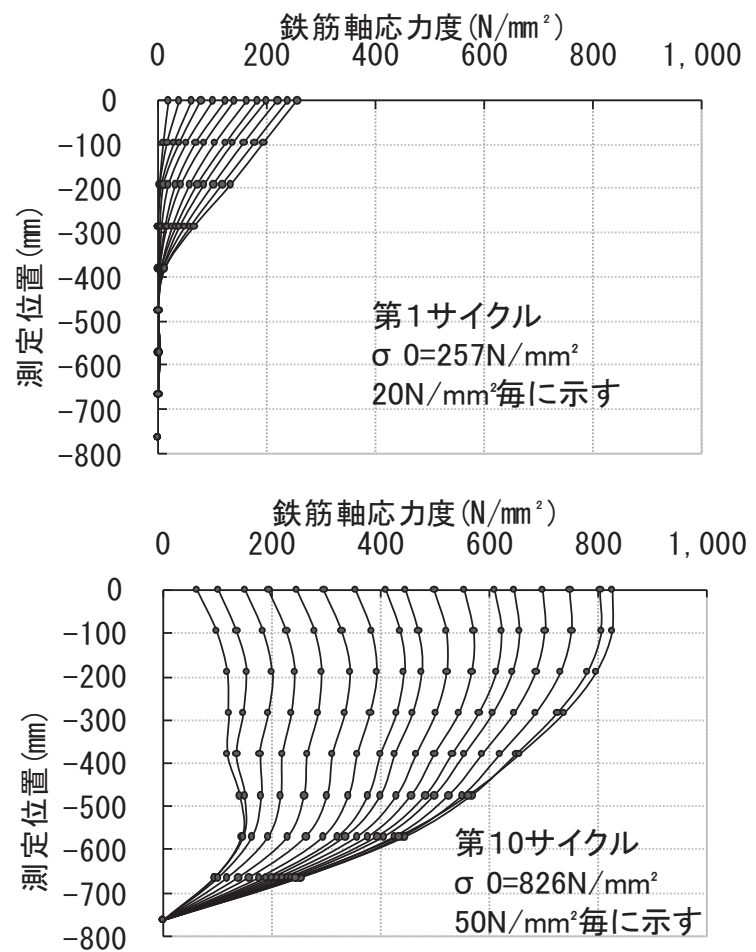

図 9 軸応力度分布（試験体 No, 6 梁幅 $220 \mathrm{~mm}$ ）
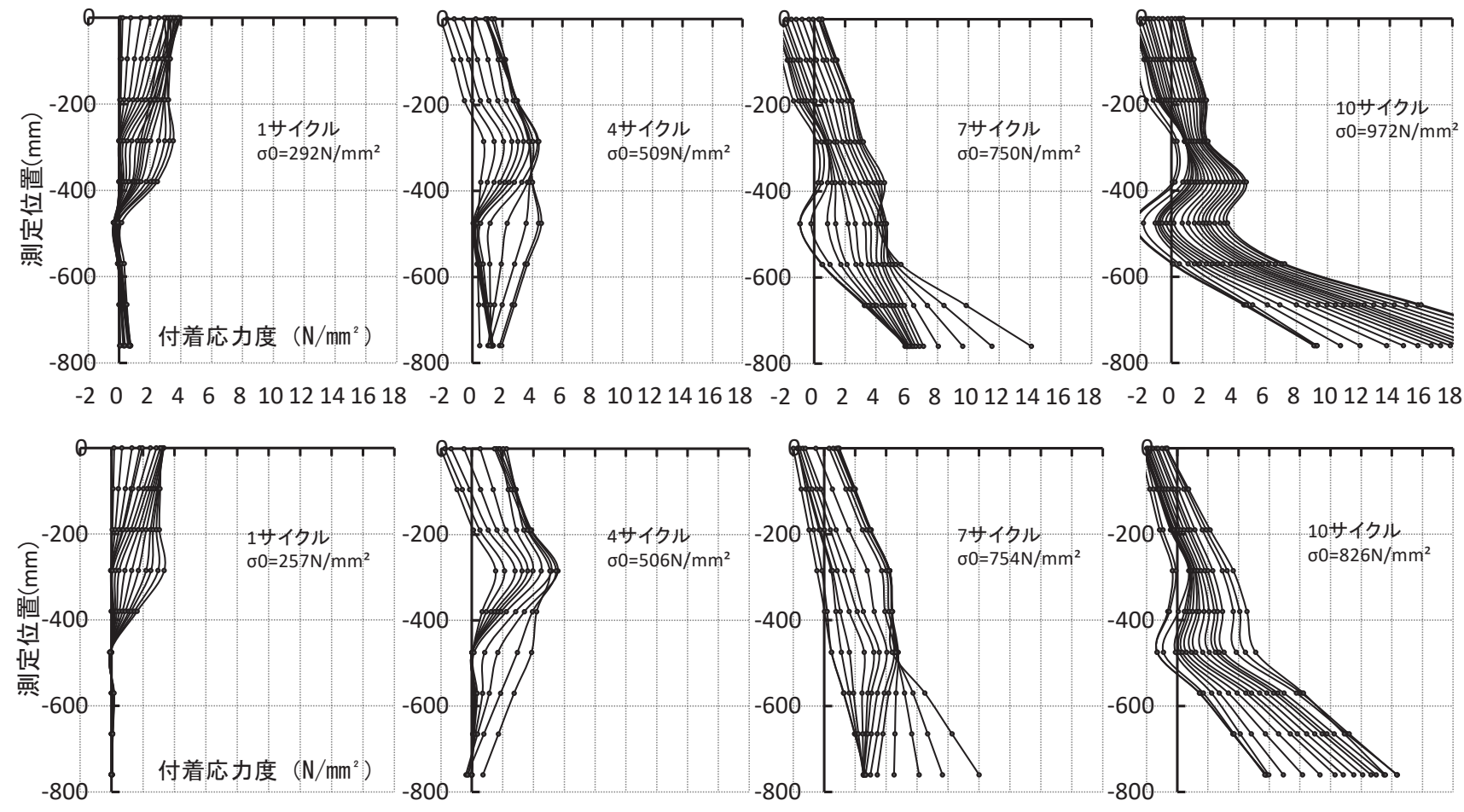

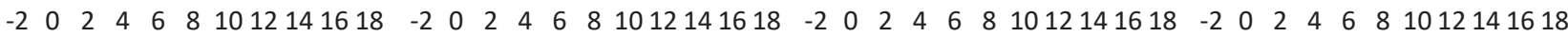
図 10 付着応力度分布 上段（梁幅 $180 \mathrm{~mm}$ ） 下段（梁幅 $220 \mathrm{~mm}$ ） 

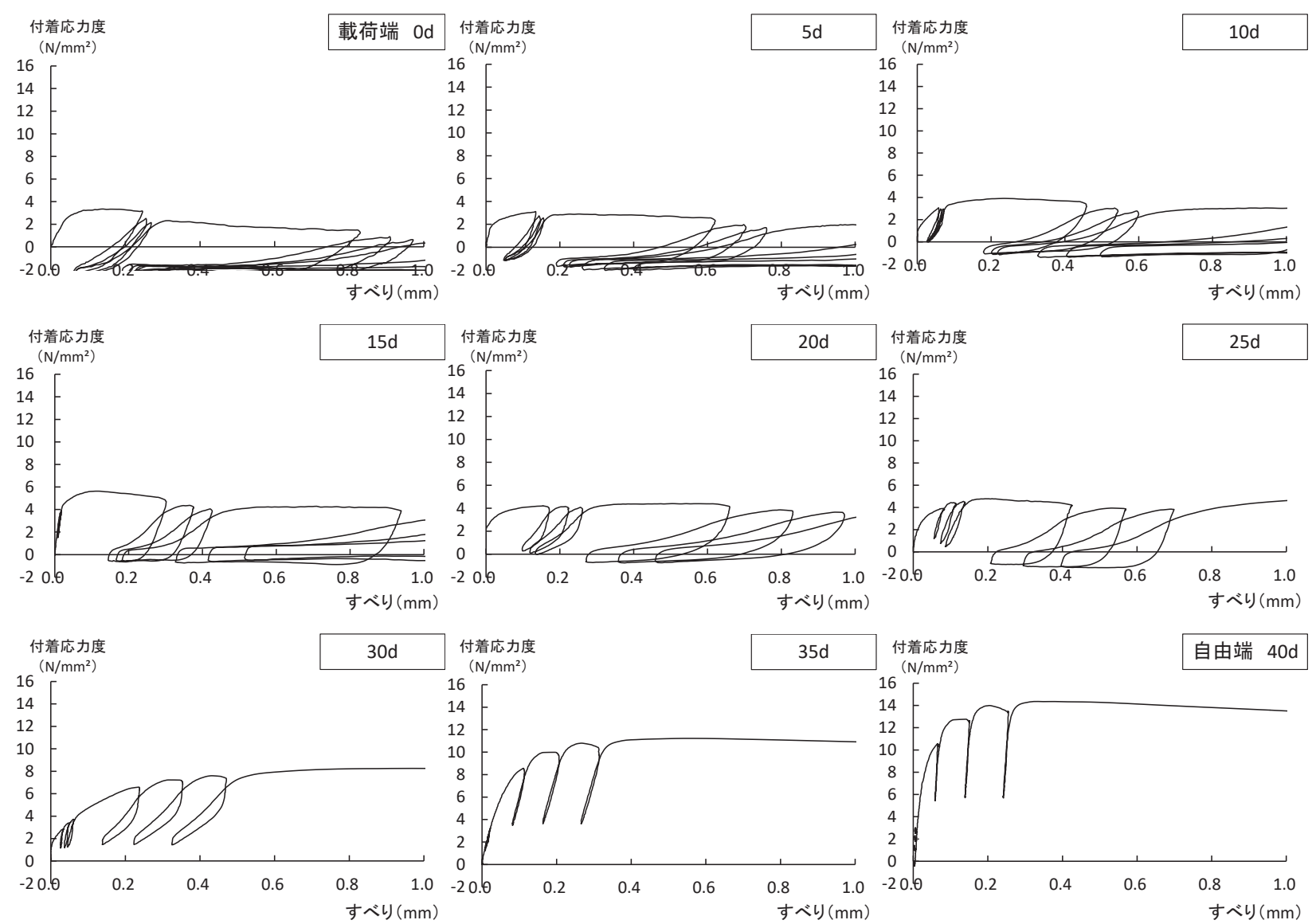

図 11 付着応力度 $(\tau)$ 一すべり $(S)$ 関係（試験体 No.6 梁幅 220mm）

それ以上のすべりでは付着破壊のため付着耐力が低下している。 30d から 40d では，すべりが $1 \mathrm{~mm} ， 0.6 \mathrm{~mm} ， 0.3 \mathrm{~mm}$ で大きな付着 応力度に達し, それ以降付着破壊のため耐力が減少した。他の試験 体についてもほぼ同様の傾向がみられた。

(4) 付着応力度 $(\tau)$ - 曲げ応力度 $\left({ }_{0} \sigma\right)$ 関係

梁中央曲げモーメント M から, 断面の位置 $\mathrm{Y}$ （梁上面で 0）ま たはy（中立軸で 0$)$ における曲げ応力度 $(\mathrm{c} \sigma)$ を次式で算定した。

$$
\begin{array}{cl}
{ }_{c} \sigma=\frac{M}{I_{\mathrm{e}}} y=\frac{a_{a} \sigma_{0} L}{4 I_{e}} y= & \frac{a_{a} \sigma_{0} L}{4 I_{e}}\left(D-x_{n}+Y\right) \\
\text { ここで, } \sigma_{0} & : \text { 荷重に相当する軸応力度 } \\
L & : \text { 梁曲げスパン } \\
I_{e} & \text { : 有効断面二次モーメント } \\
D & : \text { 梁全せい } \\
x_{n} & : \text { 中立軸から圧縮縁までの距離 }
\end{array}
$$

$x_{n}$ と $I_{e}$ の算出方法を次に示す。ひびわれが図 12 の断面途中である $\mathrm{Y}$ 位置まで進展したとき, 断面 1 次モーメント $(S e)$ は次式となる。

$$
\begin{aligned}
\mathrm{S}_{e}= & -\frac{b}{2} x_{n}{ }^{2}+\frac{b}{2}\left(D+Y-x_{n}\right)^{2} \\
& +n\left\{\sum a_{t i}\left(\frac{D+d_{i}}{2}-x_{n}\right)\right\}+(n-1)\left\{\sum a_{c i}\left(\frac{D-d_{i}}{2}-x_{n}\right)\right\}
\end{aligned}
$$

$$
\begin{array}{ll}
\text { ここで, } x_{n} \geqq 0, \mathrm{Y} \leqq 0 \text { とし }, \\
a_{t i} & : \text { 引張鉄筋断面積 } \\
a_{c i} & : \text { 圧縮鉄笳断面積 } \\
d_{i} & : \text { 各段鉄筋間距離 } \\
n & : \text { ヤング係数比 }
\end{array}
$$

断面合力のつり合いより， $x_{n}$ を求める。

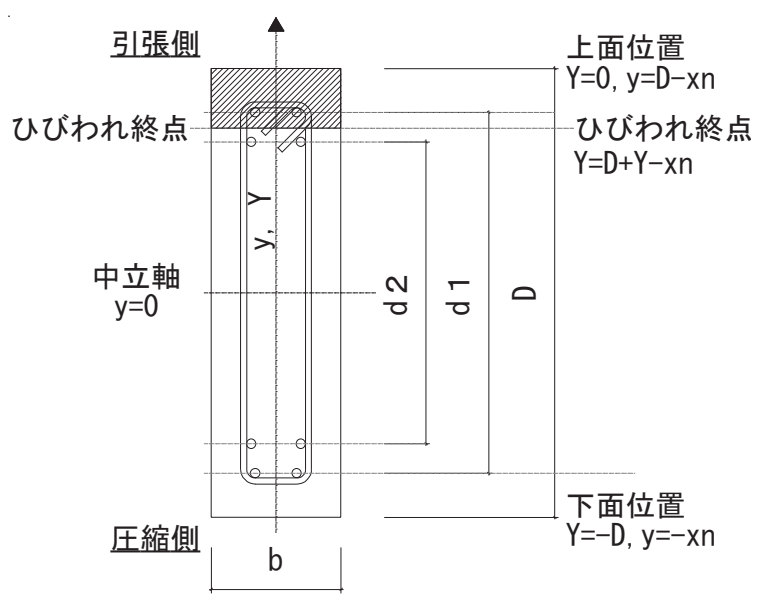

図 12 ひびわれ後の断面 
$\mathrm{S}_{e}=-A x_{n}+B=0$

$\therefore x_{n}=B / A$

ただし，

$A=n\left(\sum a_{t i}\right)+(n-1)\left(\sum a_{c i}\right)+b(\mathrm{D}+\mathrm{Y})$

$B=n\left\{\sum a_{t i}\left(\frac{D+d_{i}}{2}\right)\right\}+(n-1)\left\{\sum a_{c i}\left(\frac{D-d_{i}}{2}\right)\right\}+\frac{b}{2}(\mathrm{D}+\mathrm{Y})^{2}$

曲げモーメント $\mathrm{M}$ の式より, $I_{e}$ を求める。

$\varepsilon=\phi y \quad($ コンクリート，鉄筋共通）

$\sigma=E \varepsilon=E \phi y \quad$ (コンクリート, 鉄筋共通)

${ }_{c} \sigma_{c}=-{ }_{c} E \phi x_{n}$ （コンクリート圧縮縁応力度）

$M=\sum a_{t i} \sigma_{t i}\left(\frac{D+d_{i}}{2}-x_{n}\right)+\sum a_{c i s} \sigma_{c i}\left(\frac{D-d_{i}}{2}-x_{n}\right)$

$$
-\frac{b x_{n}{ }^{2}{ }_{c} \sigma_{c}}{3}\left\{1+\left(\frac{\mathrm{D}+\mathrm{Y}-x_{n}}{x_{n}}\right)^{3}\right\}
$$

$={ }_{c} E \phi I_{e}$

$\therefore I_{e}=n\left\{\sum a_{t i}\left(\frac{D+d_{i}}{2}-x_{n}\right)^{2}\right\}+(n-1)\left\{\sum a_{c i}\left(\frac{D-d_{i}}{2}-x_{n}\right)^{2}\right\}$

$$
+\frac{b x_{n}{ }^{3}}{3}\left\{1+\left(\frac{\mathrm{D}+\mathrm{Y}-x_{n}}{x_{n}}\right)^{3}\right\}
$$

荷重の初期は全断面有効の弾性計算で曲げ応力度を求め, 上部で 曲げ応力度がテストピースの割裂引張強度に達した時点で, その位 置までコンクリート断面を無視した引張無視の弾性計算で曲げ応力 度分布を求めた。 $5 \mathrm{~d}$ 毎の曲げひびわれの進行を確認し, 逐次, ひび われ断面を無視する計算を行い, この $\mathrm{c} \sigma$ とての関係を求めた。

梁幅 $220 \mathrm{~mm}$ の試験体について, 各鉄筋位置における $\tau-{ }_{\mathrm{c}} \sigma$ 関 係を, 図 13 に示す。

定着位置が $0 \mathrm{~d}$ から $15 \mathrm{~d}$ までは, 。 $\sigma$ が割裂引張強度未満の $1.7 \mathrm{~N} /$ $\mathrm{mm}^{2}$ 以下の応力で， $\tau$ が最大となっている。 $20 \mathrm{~d}$ と $25 \mathrm{~d}$ では， c $\sigma$

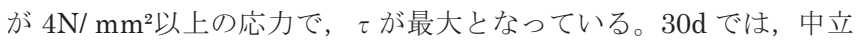

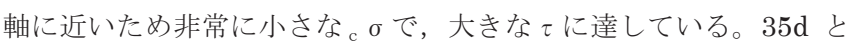
$40 \mathrm{~d}$ では $\sigma$ が圧縮の值となり, 拘束の効果で非常に大きな $\tau$ にな った。

他の試験体においても，同様の傾向がみられている。

以上のように，上部では曲げひびわれ発生前に付着応力度は極大 となる。ひびわれ発生後の引張の曲げ応力度は鉄筋の表面にかかる 実際の応力ではなく, 応力は 0 で引張歪が増大していることになる。 自由端側で圧縮応力度が増大寸ると付着応力度は引張側よりも非常 に大きくなる結果となった。

\section{（5）各応力度とすべりの関係}

以上の分析を各試験体に適用した結果，アンカー筋を $5 \mathrm{~d}$ ピッチ に分けその位置における最大付着応力度 $(\tau \max )$ と, 最大時の曲 げ応力度（ $c_{c} \sigma ）$ およびすべり（S）が得られた。

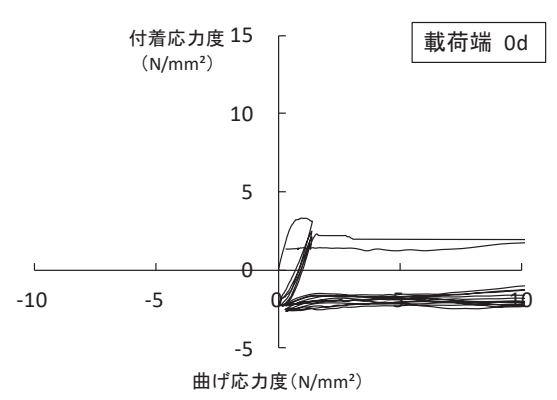

曲げ応力度 $\left(\mathrm{N} / \mathrm{mm}^{2}\right)$

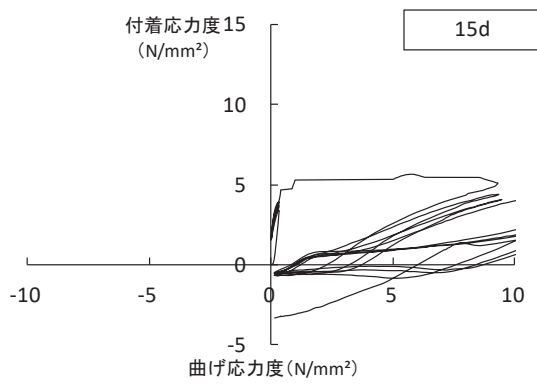

曲げ応力度 $\left(\mathrm{N} / \mathrm{mm}^{2}\right)$

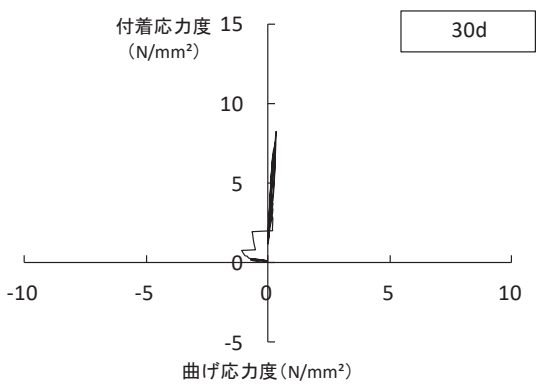

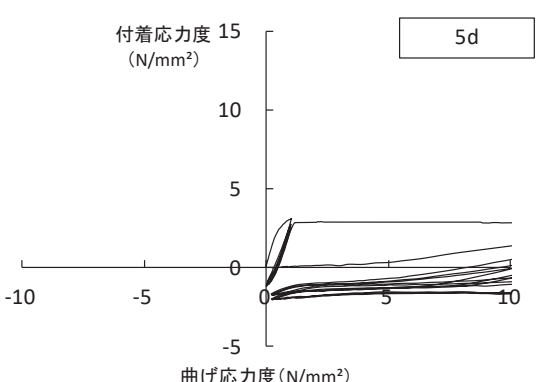

曲げ応力度 $\left(\mathrm{N} / \mathrm{mm}^{2}\right)$

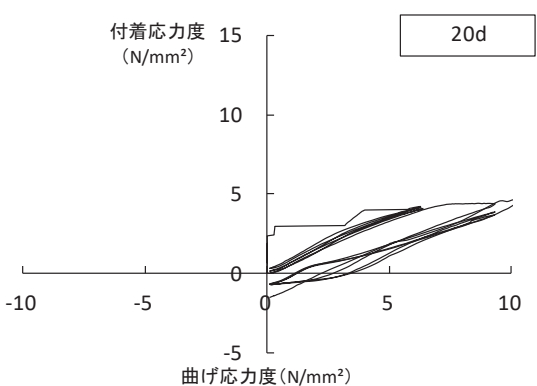

曲げ応力度 $\left(\mathrm{N} / \mathrm{mm}^{2}\right)$

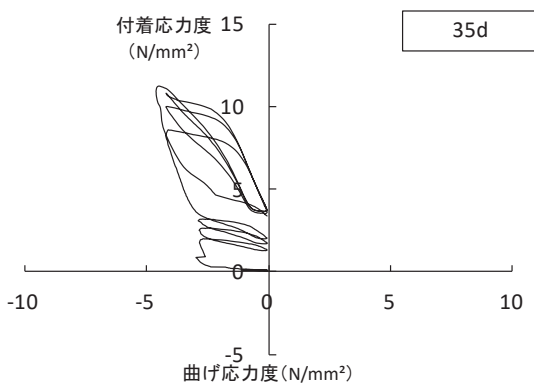

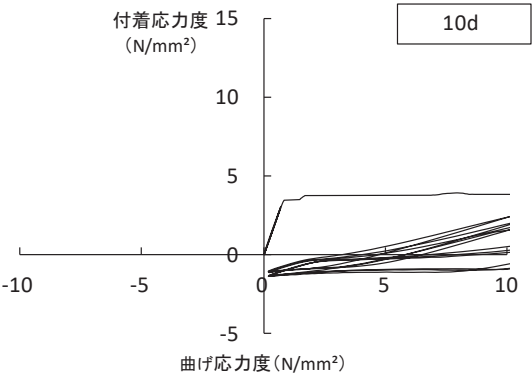

曲げ応力度 $\left(\mathrm{N} / \mathrm{mm}^{2}\right)$

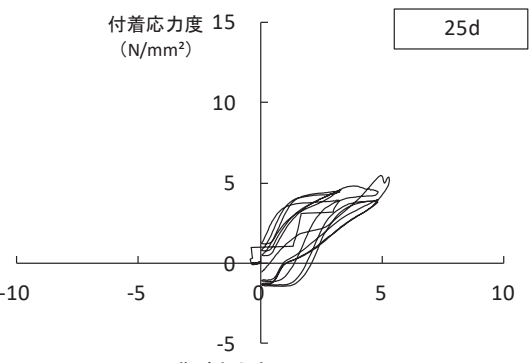

曲げ応力度 $\left(\mathrm{N} / \mathrm{mm}^{2}\right)$

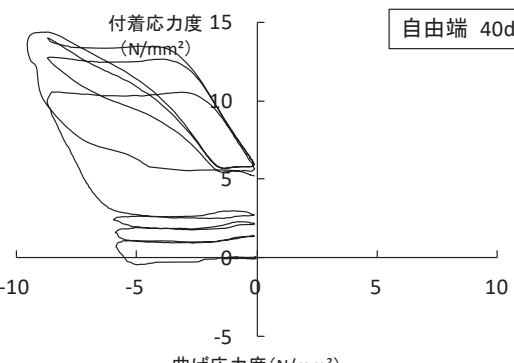

曲げ応力度 $\left(\mathrm{N} / \mathrm{mm}^{2}\right)$

図 13 付着応力度 $(\tau)$ 一曲げ応力度 $\left({ }_{c} \sigma\right)$ 関係 （試験体 No. 6 梁幅 220mm） 
表 3 最大付着応力度 $\tau \max \left(\mathrm{N} / \mathrm{mm}^{2}\right)$ ，すべり $\mathrm{S}(\mathrm{mm})$ ，曲げ応力度。 $\sigma\left(\mathrm{N} / \mathrm{mm}^{2}\right)$ 一覧

\begin{tabular}{|c|c|c|c|c|c|c|c|c|c|c|}
\hline \multicolumn{2}{|c|}{} & $0 \mathrm{~d}$ & $5 \mathrm{~d}$ & $10 \mathrm{~d}$ & $15 \mathrm{~d}$ & $20 \mathrm{~d}$ & $25 \mathrm{~d}$ & $30 \mathrm{~d}$ & $35 \mathrm{~d}$ & $40 \mathrm{~d}$ \\
\hline \multirow{3}{*}{ 梁幅180 } & $\tau \max$ & 4.06 & 3.32 & 3.23 & 4.42 & 4.56 & 5.38 & 7.26 & 16.01 & 24.75 \\
& $\mathrm{~S}$ & 0.191 & 0.1 & 0.12 & 0.164 & 0.744 & 0.212 & 0.772 & 0.481 & 0.368 \\
& ${ }_{\mathrm{c}} \sigma$ & 1.36 & 1.02 & 4.35 & 4.95 & 4.61 & 4.19 & 0.27 & -6.44 & -13.15 \\
\hline \multirow{3}{*}{ 梁幅220 } & $\tau \max$ & 3.35 & 3.1 & 3.91 & 5.63 & 4.41 & 4.78 & 8.26 & 11.22 & 14.36 \\
& $\mathrm{~S}$ & 0.14 & 0.135 & 0.234 & 0.115 & 0.505 & 0.194 & 0.97 & 0.566 & 0.323 \\
& ${ }_{\mathrm{C}} \sigma$ & 0.96 & 1.06 & 1.7 & 1.01 & 4.01 & 4.92 & 0.35 & -4.48 & -8.67 \\
\hline \multirow{3}{*}{ 梁幅330 } & $\tau \max$ & 8.25 & 6.44 & 5.64 & 6.98 & 6.62 & 7.38 & 9.6 & 13.18 & 17.79 \\
& $S$ & 0.258 & 0.212 & 0.361 & 0.186 & 0.777 & 0.289 & 0.985 & 0.979 & 0.968 \\
& ${ }_{C} \sigma$ & 1.27 & 1.19 & 2 & 1.19 & 0.4 & 4.97 & 1.2 & -4.45 & -10.06 \\
\hline \multirow{2}{*}{ 梁幅440 } & $\tau \max$ & 8.02 & 6.3 & 5.65 & 7.2 & 5.26 & 7.9 & 9.84 & 13.5 & 17.45 \\
& $S$ & 0.252 & 0.265 & 0.179 & 0.153 & 0.974 & 0.195 & 0.723 & 0.995 & 0.833 \\
& ${ }_{c} \sigma$ & 0.99 & 1.03 & 0.76 & 0.43 & 0 & -0.41 & 1.37 & -3.49 & -8.17 \\
\hline
\end{tabular}

表 3 にそれらを示す。 $\tau$ max は大きな $\mathrm{S}$ の時に漸増することが ある。これを無視して $\mathrm{S} か ゙ ~ 1 \mathrm{~mm}$ 以内で最大になった值としている。

載荷端 $0 \mathrm{~d}$ から $25 \mathrm{~d}$ 程度までの。 $\sigma$ が引張の領域では, 梁幅 $180 \mathrm{~mm}$ と梁幅 $220 \mathrm{~mm}$ の試験体では, $\tau \max$ が $3 \sim 5 \mathrm{~N} / \mathrm{mm}^{2}$ 程度になってい るのに対して, 梁幅 $330 \mathrm{~mm}$ と梁幅 $440 \mathrm{~mm}$ の試験体では $\tau \max$ は $5 \sim 8 \mathrm{~N} / \mathrm{mm}^{2}$ 程度になっている。30d 35d の間に最終的な中立軸が位 置している。30d 40d の自由端方向に $\tau$ max は非常に大きくなり, 自由端では $25,14,18,17 \mathrm{~N} / \mathrm{mm}^{2}$ の極大值を示した。

図 14 に $\tau$ max と。 $\sigma$ の関係を示す。まず $。$ $\sigma$ の引張側を見ると, 梁幅 $180 \mathrm{~mm}$ および $220 \mathrm{~mm}$ の群と, $330 \mathrm{~mm}$ および $440 \mathrm{~mm}$ の群と で別れており, 梁幅で $\tau$ max に大小の差が見られた。また, $\sigma$ が引 張で小さいか圧縮の, 自由端の測定点から数えて 3 つ目の $30 \mathrm{~d}$ から 自由端の測定点まで, 直線的に $\tau \max$ が増加する傾向があり, 梁幅 $180 \mathrm{~mm}$ の場合は最も圧縮応力度による拘束効果が大きく出ている。 梁幅 220, 330, 440 では梁幅 180 と比較して $\sigma$ 。の効果は控えめと なり， c $\sigma$ が引張側の 0 30d 区間では, c $\sigma$ と $\tau \max$ の関係につい て相関性は薄いと思われる。

\section{4. 結論}

本研究の範囲内で以下の知見を得た。

（1）プレキャスト壁式鉄筋コンクリート構造の，住宅などの基礎に 使用するアンカー筋として, D19, SD345 の異形鉄筋を 40d の直線定着で用いることは, 実用上問題はなく, シース管を用 いてあと施工で定着すれば抜け出し変形を抑制でき性能が高 まる。

（2）アンカー筋の付着破壊は, 荷重の上昇とともに梁の上部から下 部へ各個撃破で進行する。

（3）アアンカー筋の引き抜きで梁に曲げモーメントが生じる場合, 梁 断面の曲げ圧縮応力度は最大付着応力度を高める。

（4）曲げ引張応力度または引張歪度は, 曲げ圧縮応力度ほどには最 大付着応力度に影響を与えない。

（5）曲げ引張応力度または引張歪度と最大付着応力度の相関性は 低いが，梁幅の影響はある。

（6）曲げ圧縮応力度と最大付着応力度の関係は線形であり, その勾 配は梁幅 180 で大きく梁幅 220 以上では一定となり, それぞ れの近似直線の $\mathrm{y}$ 切片は梁幅に応じて大となる。

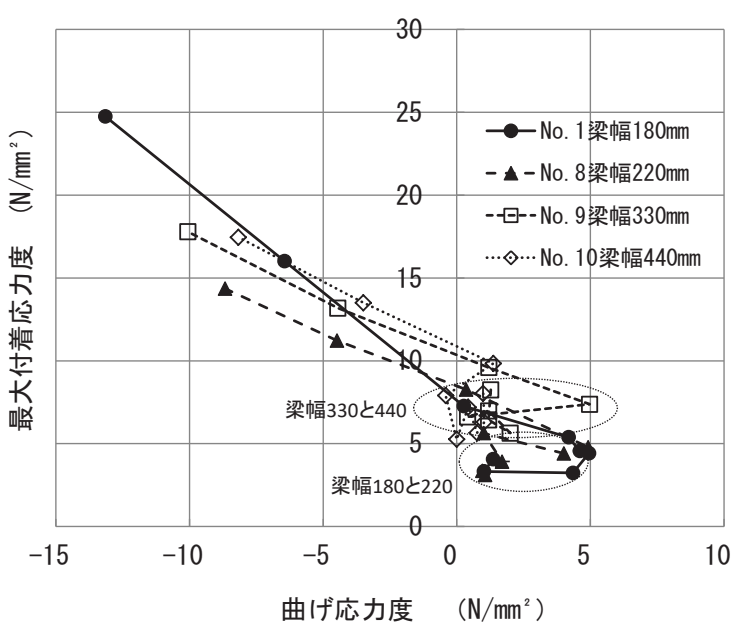

図 14 最大付着応力度一曲げ応力度関係

謝辞

実験の遂行に際し，レスコハウス株式会社に実証実験の一部の援助 を受け，東京鉄鋼株式会社から，SD685, SD980の異形鉄筋の提供 を受け, 横内工業株式会社から主筋や補強筋の寄付を頂いた。また, 2011 年からの千葉工業大学, 中野研究室の卒研生, 院生には実験の 手伝いをしていただいた。関係各位に感謝致します。

\section{参考文献}

1）日本建築学会：鉄筋コンクリート構造計算規準・同解説， 2010

2）日本建築学会：壁式鉄筋コンクリート造設計・計算規準・同解説，2015

3）土木学会規準 : 引抜き試験による鉄筋とコンクリートとの付着強度試験 方法, JSCE-G 503-2007

4）建材試験センター：引抜試験による鉄筋とコンクリートの付着強さ試験 方法, JSTM C 2101:1999

5）徳重充，石橋一彦，中野克彦：異形鉄筋の定着性状に及ぼす拘束の効果 に関する実験的研究, その 1 シース管に埋設されたアンカー筋の定着性 状，日本建築学会大会学術講演梗概集，構造IVpp．525～526，2015.9

6）石橋一彦, 徳重充, 中野克彦: 異形鉄筋の定着性状に及ぼす拘束の効果 に関する実験的研究 : その 2 曲げモーメントを受ける梁の付着領域と梁 幅の影響, 日本建築学会大会学術講演梗概集, 構造IVpp. 527 528, 2015.9

7）徳重充, 石橋一彦, 中野克彦: 異形鉄筋の定着性状に及ぼす拘束の効果 に関する実験的研究: 日本コンクリート工学会年次論文集, pp. 655〜 660, 38 巻 2 号, 2016.8 


\title{
EXPERIMENTAL STUDY ON CONCRETE CONFINEMENT \\ AROUND A DEFORMED STEEL BAR DEVELOPING STRAIGHT
}

\author{
Mitsuru TOKUSHIGE* , Kazuhiko ISHIBASHI** and Katsuhiko NAKANO*** \\ * Engineering Specialty, Engineering Postgraduate Course, Chiba Institute of Technology, M.Eng. \\ ** Prof. Emeritus, Chiba Institute of Technology, Dr.Eng. \\ *** Prof., Chiba Institute of Technology, Dr.Eng.
}

Vertical wall reinforcing bars of a boxed wall precast concrete structure in Japan must be anchored straight in the foundation beam. Sometimes, the beam width may not be sufficient to develop anchorage strength in the concrete although the AIJ (Architectural Institute of Japan) Standard for Structural Calculation of Reinforced Concrete Structure requires minimum concrete volume for the development of deformed bars. A series of pull-out tests were carried out to investigate structural performance of anchored bars using various prototype specimens. The purpose of the test series was to study the effect of various parameters and to clarify the failure mechanism. A new series of tests were carried out using high strength deformed bars and varying the foundation beam widths. The anchored bars were pulled out from the base beam exhibiting the relationship between maximum bond stresses and flexural stresses with in the beam

It can be concluded as follows:

(1) D19 (diameter $19 \mathrm{~mm}$ ) deformed bars of Grade SD345 and SD685 (nominal yield stress of 345 and $685 \mathrm{MPa}$ ) can be anchored with a development length of $40 \mathrm{~d}$ (d: bar diameter) for the precast reinforced concrete box-wall construction. When deformed bars are anchored using sheath pipes after construction of the beam, the sufficient development strength was achieved.

(2) D19 deformed bars of Grade SD980 were pulled out of the beams of 180, 220, 330, and 440mm widths.

(3) Bond failure of a deformed bar developed from the beam top and progresses to deeper region with load.

(4) Flexural compressive stresses in the foundation beam increased bond resistance of the deformed bars.

(5) Flexural tensile stress or strain of concrete in the foundation beam had less influence on the bond resistance along a deformed bar.

(6) The beam width had not much effect on the development strength of a deformed bar within the foundation beam.

(7) The development strength of deformed bars was proportional to the flexural compressive stresses in the foundation beam.

(8) The development strength increased at a higher rate for beam width less than $180 \mathrm{~mm}$, but the increase rate became smaller for the beam width more for $220 \mathrm{~mm}$ to $440 \mathrm{~mm}$. 